\title{
Konutlardaki Mutfak Yangınları Üzerine Bir Değerlendirme
}

\author{
Zehra Y1ldız \\ Tarsus Üniversitesi, Mühendislik Fakültesi, Makine Mühendisliği Bölümü, Mersin, Türkiye, (ORCID: 0000-0003-1304-4857), zyildiz@tarsus.edu.tr
}

(İlk Geliş Tarihi 31 Ağustos 2020 ve Kabul Tarihi 31 Ocak 2021)

(DOI:10.31590/ejosat.788253)

ATIF/REFERENCE: Yıldız, Z. (2021). Konutlardaki Mutfak Yangınları Üzerine Bir Değerlendirme. Avrupa Bilim ve Teknoloji Dergisi, (21), 621-628.

$\ddot{O} \mathbf{z}$

Yemek yapılan ya da yemek servisi sunan lokanta, hazır yemek firmaları, işyeri veya konut mutfakları yapının dar bir bölümü olup, başta 1sıtma-pişirme ekipmanları olmak üzere birçok elektrikli cihazın kullanıldığı yangın yükü indeksi fazla olan bir bölgedir. Ülkemizde meydana gelen yangınların yaklaşık yarısı konutlarda meydana gelmektedir. Konutlarda meydana gelen yangınların çoğu, mutfaklarda ortaya çıkmakta ve konutun diğer bölmelerine yayılarak yangının büyümesine neden olmaktadır. Bu çalışmada, Mersin ilinde meydana gelen yangınlar ile beraber mutfak yangınlarının nedenleri ve mutfak yangınlarını önlemek için alınabilecek tedbirler ortaya konmuştur. Mersin ilinde meydana gelen yangınlar incelendiğinde en fazla karşılaşılan yangın türü sırasıylaot yangını, konut yangını, atık yangını ve araç yangını olduğu belirlenmiştir. Mutfak yangınlarına genel olarak yağ buharı ve isıtma-pişirme sistemleri sebep olduğu belirlenmiştir. Mutfak yangınları, alınabilecek basit önlemlerle engellenebilir düzeyde olduğu görülmüştür.

Anahtar Kelimeler: Yangın, Konut yangını, Mutfak yangını, Yă̆ yangını

\section{An Evaluation on Kitchen Fires in Buildings}

\begin{abstract}
Restaurants, catering companies, workplace or residential kitchens that serve food or cater are a narrow part of the building, and it is a region with a high fire load index where many electrical devices are used, especially heating-cooking equipment. Approximately half of the fires in our country occur in residences. Most of the fires that occur in residences occur in kitchens and spread to other parts of the house, causing the fire to grow.In this study, the causes of kitchen fires along with the fires in Mersin province and the measures that can be taken for fire prevention are presented. When the fires that occurred in Mersin province were examined, it was determined that the most common type of fire was grass fire, house fire, waste fire and vehicle fire, respectively. It has been revealed that kitchen fires are generally caused by oil mist and heating-cooking systems. Kitchen fires can be prevented by simple measures.
\end{abstract}

Keywords: Fire, Home fire, Kitchen fire, cooking oil fire

\footnotetext{
*Sorumlu Yazar: zyildiz@ tarsus.edu.tr
} 


\section{Giriş}

Yangın, kontrol edilemeyen istenmeyen zincirleme yanma reaksiyonudur. Yanma, yanıcı madde, oksijen ve tutuşma sıcaklığına yetecek kadar ısının bir araya gelmesi ile meydana gelen kimyasal bir tepkimedir. Yanmayı sağlayan üç unsurdan yanma üçgenini oluşturan yanıcı madde, 1S1 ve oksijenden herhangi birinin eksik olması durumunda ısının çekilmesi (soğutma), hava ile teması kesmek (boğma) ve yakıtı ortamdan uzaklaştırmak gibi durumlarda yanma gerçekleşmemektedir. Mutfakta tahta, metal, kağıt, kumaş ve plastik malzemelerden yapılmış gereçler bulunmakta olup, yanıcı özelliklidirler. Havanın \%21'i oksijenden oluşmakta olup, mutfakta yanabilme aralığına yetecek kadar oksijen bulunmaktadır. Yanıcı madde ve oksijen her zaman mutfak ortamında bulunmaktadır. Yanma üçgeninin bu iki kenarı uygun oranlarda bulunduğunda üçüncü kenar 1S1 sağlandığında yanma üçgeni tamamlanır ve yangın meydana gelir.

Mutfaktaki yangınların iki ana sebebi vardır: yağ buharı ve 1sıtma-pişirme cihazları. Yanma olayında yanıcı madde öncelikle ortamdan 1s1 alarak buhar haline gelmesi gerekir sonra bu buhar ısınarak genleşir yangına ve yangının yayılmasına sebebiyet verir. Yanma olayında 1S1, yanıcı maddenin tutuşmasını sağlayan kendi kendine yanmayı besleyecek buharın üretilebildiği sıcaklıktır. Yağ buharı, 1sı ve yanıc1 buharı taşımaktadır. Yağ buharı yoğuştuğu durumda yağ tabakasına neden olmakta ve uygun koşullarda bu tabaka yanabilir durumdadır. Gazla ya da elektrikle çalışan birçok 1sı kaynağı mutfakta bulunmaktadır. Mutfakta kullanılan 1sıtma-pişirme cihazları da yanma için gerekli ısıyı sağlamaktadır. Yanma üçgenin üç unsuru mutfak ortamında bulunmaktadır. Bu yüzden, mutfaklar yangın riski barındıran ortamlar olup, gerekli önlemlerin alınmaması durumunda yangın mutfaktan başlayarak yapının diğer kısımlarına yayılarak büyüyebilir.

Mutfak, tavan, taban, duvar, pencere ve kapılarla etrafi sınırlandırılmış kapalı bir mekandır. Mutfaktaki yangın, kapalı alan yangınları içerisinde değerlendirilir. Yanma, hız ve müdahale yöntemi açık alan yangınlarından farklıdır. Kapalı bir mekanda yangın ilerledikçe havadaki oksijen tükenmekte yanmamış gazlardan oluşan duman miktarı artmaktadır. Mutfakta yangın başladıktan sonra hava yanma olayı için tüketildiğinden azalır ve yanma sıcak tütme denilen aşamaya geçer. $\mathrm{Bu}$ aşamada, oksijen yetersizliğinden dolayı yanmamış gazlar tavanda birikmiş halde olup, kapı veya pencere açıldığında oksijenin içeri girmesi ile yanmamış gazlar parlayarak yanar. Bu tehlikeli duruma geri tepme denir (Bakırc1, 2020).

Yangınlar, yapısal ve yapısal olmayan yangınlar diye iki sınıfa ayırabiliriz. Konut, fabrika, diğer bina ve araç yangınları gibi dört tarafı çevrilmiş kapalı alan yangınları yapısal yangınlardır. Ot, çöp ve orman-fundalık gibi yangınlar yapısal olmayan yangınlardır (Kara, 2018). Yapı türüne göre yangın tehlikesi, yangın yükü indeksine göre belirlenir. Yangın yükü indeksi, bir yapı içerisinde birim alan başına bulunan yanıcı madde miktarıdır. Yangın yükü indeksi, yangın şiddeti ile orantılıdır. Yangın yükü indeksine, yapılar arası boşluk, yapının şekli, boyutu vekullanılan yapı malzemesi gibi değişkenler etki eder. Yangın yükü indeksi hesabındayanıcı madde bulunmayan arazi, yol, bahçe, göl ve cadde gibi boş araziler gibi yapılar arası boşluklar da dikkate alınır. Bu sebeple yangın yükü indeksi azalır. Yangın yükü indeksi hesabı, yangın çıkarma olasılığı bulunan maddelerin fazla olması sebebiyle zordur. Ayrica, yapı bileşenleri üzerindeki yangın etkisi, sıcaklık, süre ve boyutlar ile orantılıdır (Çelik, 2019).

Yangının başlangıç evresinde ısının duvarlara ve tavana uzak olması yangının gelişim süresini geciktirir. Ancak yanma gerçekleşince yangının şiddeti artar ve yapı tamamen çökebilir. Yangının yayılmasına yangın yükü indeksine etki eden faktörler etkilidir. Yanıcı maddeler arası mesafe yapılardaki imar sıklığı arttıkça yangının yayılma tehlikesi artar. İmar sıklığı \%25 olan bölgelerde yangının bir binadan diğerine sıçrama ihtimali yoktur.

Yapılar, yangın yükü indeksine göre düşük, orta, yüksek ve çok yüksek olmak üzere grupta sınıflandırılır. Apartman daireleri düşük, hastane, hapishane, oteller ve ahşap evler, büro, ticaret ve okul binaları orta, toplantı ve eğlence yerleri ise yangın yüküne göre yüksek olan yapı tipleridir. $\mathrm{Bu}$ yapıların hemen hemen hepsinde mutfak bulunmaktadır. Mutfak yangınları da yapısal yangınların içerisinde değerlendirilmektedir. Kapalı alan yangınlarının büyük bir çoğunluğu yemek pişirme ünitelerinden çıkan yangınlar oluşturmaktadır.

Yangına müdahale yangın sınıfına göre yapılmaktadır. Bu tür sınıflandırmalar yangın durumunda yangına müdahale etme faaliyetlerini hızlandırılmasını sağlamakta ve çevreye verilebilecek zararı en aza indirgemektedir.Yanıcı maddeye göre yapılan yangın türlerinde yanıcı maddenin sıvı fazda olduğu yangınlar B, F ve K sinıfi yangınlar olarak sinıflandirılır. Ulusal Yangında Korunma Derneği (NFPA) standartlarına göre mutfak yangınları K sınıfı (kitchen) olarak sınıflandırılmıştır.Avrupa standartlarında ise F sınıfı yangınları, mutfak yangınları ya da yağ yangınları olarak bilinmektedir. Yağ yangınları özellikle yemek pişirmek ve kızartmak içinmutfaklarda kullanılan yağların tutuşma sıcaklığına kadar 1sınmasından dolayı gerçekleşir. Kızgın yağı söndürmek için bilinçsiz bir şekilde üzerine dökülen su yağ ile temas ettiğinde genleşerek yangının büyümesine sebebiyet vermekle beraber söndüren kişi hayatını tehlikeye atmaktadır. Yağ yangınlarını söndürmek için hava ile teması kesmek suretiyle müdahale yapılması gerekirve F sınıfı potasyum içerikli yangın söndürme maddesi kullanılır (Mamacığlu ve ark., 2017; Çelik, 2019; Tüyander 2020). Yağ buharlarının yoğuşarak davlumbaz birikmesi ve bu yağ tabakasının iyi temizlenmemesi durumunda da davlumbaz yangınları çıkmaktadır. Ocak için kullanılan likit petrol gazı (LPG) tüplerinin patlaması C sınıfı yangınları ya da mutfakta bulunan elektrikli cihazlarından kaynaklı E sınıfı elektrik yangınları da çıkabilmektedir.

\section{Mersin İlinde Yaşanan Yangınlar}

Mersin, ülkemizin tarım ve turizm faaliyetlerinde önde gelen bir şehridir. Mersin büyükşehir belediyesi itfaiyesi 2019 verilerine göre Mersin ilinin tatil bölgelerinde yer alan otellerindeyangın meydana gelmemesi, turizmdeyangın güvenliği açısından güvenli bir şehir olduğunu göstermektedir. Ayrıca şehirde bulunan banka, büro, muayane ve işhanı gibi kapalı mekanlarda yangın ortaya çıkmadığı görülmüştür.Şekil 1 den görüldüğü üzere 2019 yılı Mersin ilinde sirasıyla en fazla ot yangını, konut yangını, atık yangını, araç yangını, çöp yangını, çalılık ve ağaç yangını meydana gelmiştir. Yaz mevsimi ile 
Sıcaklık artması ot yangınlarında artmasına sebep olduğu söylenebilir. Mersin ili yılın 300 günü güneşlenme potansiyeli olan yaş sebze ve meyve üretiminde önde gelen bir şehirdir. Tarım ve ormanlık alanlarının fazla olması nedeniyle ot, saman, çalılık ve orman yangını fazla olmaktadır. Bu tür açık alan yangınları hava sıcaklığının arttığı yaz aylarında daha fazla olduğu görülmüştür. Atık, çöp, ot, konut yangınları ise en fazla Akdeniz, Toroslar ve Tarsus ilçelerinde meydana gelmiştir (Mersin Büyükşehir Belediyesi İtfaiye Başkanlığı, 2020). Mersinin bu ilçeleri nüfus yoğunluğunun, çarpık kentleşmenin, göç ederek yerleşenlerin fazla olduğu ve eğitim seviyesinin daha düşük olduğu yerleşim birimlerindendir.

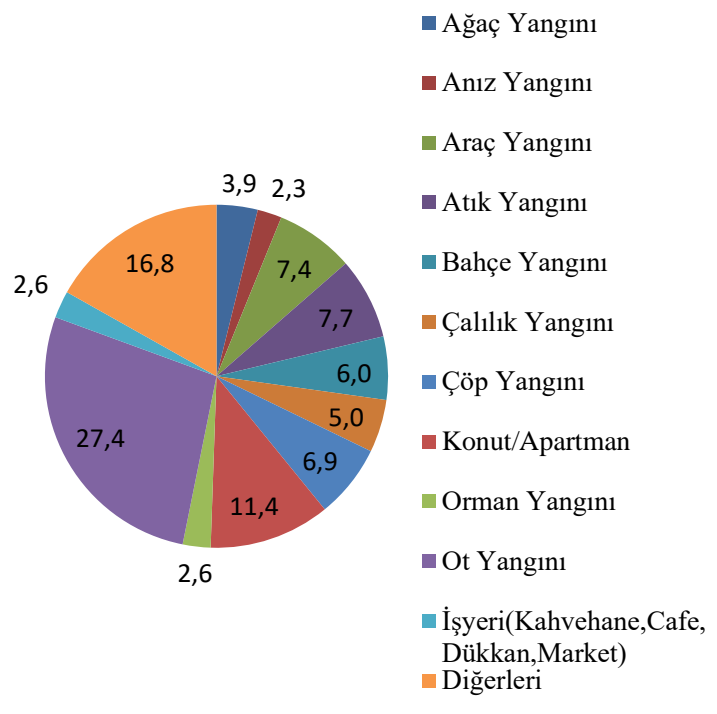

\section{Şekil 1.Mersin ilinde yaşanan yangınlar}

Ülkemizde meydana gelen yangınların yaklaş1k \%45'i konutlarda meydana gelmektedir. Konutlar yangınlarının \%40'1 mutfak, \%20'si soba ve elektrikli 1sitıcı gibisstma kaynakları, $\% 10$ sigara ve $\% 5$ elektrik ve çocuklardan dolayı gerçekleşmektedir (Kara ve Kara, 2018; Kılıç, 2014). Konutlarda meydana gelen yangınlarda, yangının çıktığı daire yanarken yangın yükü düşük olduğundan genellikle diğer dairelere yangin yayılmaz. Ancak duman, merdiven boşluğundan binanın tamamına yayılabilir (Kılıç, 2014). Yangınlarda meydana gelen ölümlerin sebebi, bina yangın güvenlik önlemlerine, yanıcı madde bileşimi, miktarı ve hane halkın yaşam şekline bağlıdır (Kılıç, 2018).

Mersindeki kapalı alan yangınlarında, konut yangınları ilk sıradadır. Konut yangınlarının yaklaşık \%35'i kış döneminde Ocak-Şubat-Mart döneminde gerçekleşmiştir. Ortalama her yıl toplam 700-900 arasında özel ve kamu konutlarında yangın meydana gelmiştir. Mersinde konutlarda her ay ortalama yaklaşık olarak 40-100 arasında yangın gerçekleşmiştir. Mersin ilinde 2019 yılında özel konutlarda 779 ve kamu binalarında 28 yangın meydana gelmiştir. $\mathrm{Bu}$ yangınlarda maddi hasarla beraber can kayıpları da yaşanmıştır. Mersinde en fazla konut yangını sırasıyla Akdeniz, Toroslar, Yenişehir ve Tarsus ilçelerinde meydana gelmiştir (Mersin Büyükşehir Belediyesi İtfaiye Başkanlığ 1,2020 ).

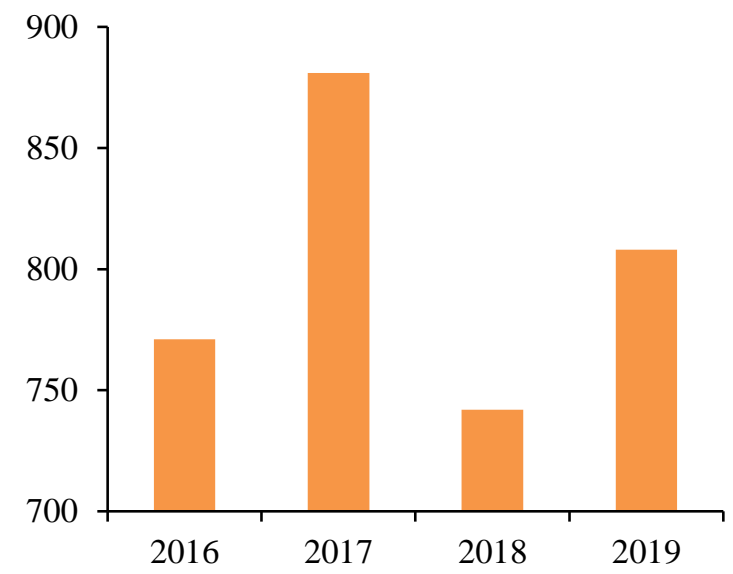

\section{Şekil 2. Yıllara göre konut yangınları değişimi}

Mersinde 2016-2019 y1lları arasında meydana gelen konut yangınları istatistiki verileri incelendiğinde konut yangınları en fazla kış mevsiminde Aralık, Ocak ve Şubat aylarında meydana geldiği görülmüştür (Mersin Büyükşehir Belediyesi İtfaiye Başkanlığı, 2020). Kış aylarında hava soğuk ve günler kısa olduğu için konut sakinleri vakitlerini evde geçirmekte dolayısıyla daha fazla kişi daha fazla süre konutta bulunmaktadır. Bu durum, insan kaynaklı ihmal ve bilgisizlik yüzünden gerçekleşebilecek yangınların olasılığını artırmaktadır. Yangın istatistiki verileri incelendiğinde Ocak ayı en fazla konut yangını meydana geldiği ay olduğu görülmüştür. Ocak ayında meydana gelen konut yangınları, yaz aylarında çıkan yangınların yaklaşık iki katı kadar fazladır. Ocak ayında havanın soğuk olması ev sakinlerinin vaktini daha fazla evde geçirmeleri ve sömestr tatilinden dolayı çocukların evde bulunması yangın çıkma olasılığ 1 artırdığı söylenebilir.

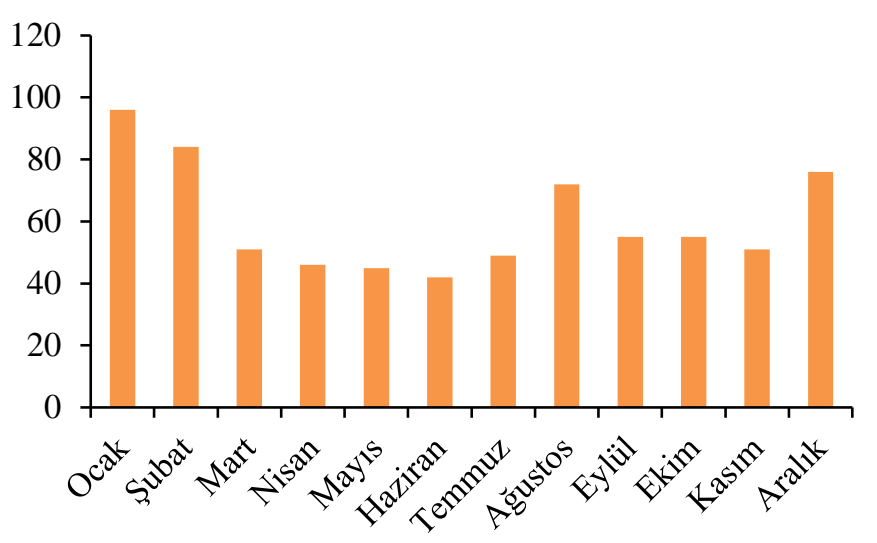

Şekil 3. Aylara göre konut yangınları değişimi

Mersin ilinde yaz aylarında sıcaklığın artmasıyla beraber tutuşma noktası düşük maddelerin yanması için gerekli 1S1 sağlandığı için ot yangını, atık yangını, araç yangını, çöp yangını, çalılık ve ağaç yangınları gibi açık alan yangınlarında artış olduğu görülmüştür. Ancak sadece konutlarda, kış aylarında yaz aylarına göre çok daha fazla yangın çıkmıştır. Konut yangınlarının çoğu mutfak bölümünde çıkmakta ve mutfakta 1sıtma-pişirme işleminden dolayı yangın çıkması için gerekli ısı kaynağı bulunması yangın riskini arttırmaktadır. 


\section{Mutfak Yangınları ve Nedenleri}

Ülkemizde meydana gelen yangınların yaklaşık $\% 45$ 'i konutlarda meydana gelmektedir (Kılıç, 2018). Bu yangınlar, elektrik kontağı, sigara, sabotaj, baca, ütü ve ocak kaynaklıdır (IBBB İtfaiye Daire Başkanlığı, 2020).Konut yangınları sırasıyla en fazla mutfak, yatak odası, oturma odası, salon ve diğer mekanlarda gerçekleşmektedir. Konutlarda meydana gelen yangınların da $\% 401$ ise mutfaklarda meydana gelmektedir. Mutfak yangınlarında günde 20 den fazla kişi ölmekte ya da yaralanmaktadır (Ahrens, 2007; Razon ve Ahmad, 2017). Mutfak, yiyeceklerin hazırlandığı ve depolandığı, yemeklerin yenildiği, bulaşıkların yıkandığı ve diğer aile bireyleri ile arkadaşların toplanıldığı özellikle bayanların daha çok zaman geçirdiği bir bölümdür. Kesici madde, sıcak ortam, gazlı veya elektrikli pişirme cihazlarının bulunduğu riskli bir ortamdır. Mutfak alanı, genelde evin veya işyerlerinin dar bir bölümüdür. $\mathrm{Bu}$ durum riskin olasılığını ve şiddetini arttıran bir faktördür.Mutfakta yanık, zehirlenme, patlama, yangın, çarpma, düşme ve kesme gibi insan hayatını tehlikeye atan olaylarla karşılaşılmaktadır. Mutfaktaki en önemli tehlike ise yangın ve patlamadir.

ABD'de NFPA (Ulusal Yangından Korunma Derneği) verilerine göre yangınların \%9'u mutfakta meydana gelmiştir. Mutfaktan diğer mekanlara yangının yayılması ile ölümlü vakaların sayısının artığı belirtilmiştir. $\mathrm{Bu}$ yüzden mutfak yangınları, yangında ölenlerin dolaylı olarak \%70'inden sorumludur. NFPA verilerine göre 2010-2014 y1llarında evlerde gerçekleşen yangınların \%33'ü ve 2013-2017 yıllarında ise $\% 49$ 'ü mutfaktameydana geldiği görülmüştür. Bu yangınlar, ölümlerin \%21'i ve yaralanmaların \%45'inden sorumludur (NFPA, 2020).

Mutfak yangınları,1sıtma-pişirme ekipmanı, elektrik, gaz sızıntıs1, tüp patlaması, yağ tutuşması, aspiratör ve bacada biriken kurumun tutuşması gibi özel nedenlerle de çıkabilmektedir. Mutfak yangının temel olarak iki nedeni vardır. Bunlar, yağ buharı ve 1sı kaynaklı gazlı veya elektrikli isıtmapişirme ekipmanlardır. Yağ buharı yoğuşarak yanıcı yağ tabakası oluşumuna ve buharın taşıdı $\breve{g} 1$ isı ile hem bu tabakanın tutuşmasına hem de ortamdaki diğer maddelerin tutuşmasına neden olur (Tüyander, 2020). Özellikle 1sıtma-pişirme ekipmanı kaynaklı mutfak yangınları çok fazladır. Mutfaklarda yiyecek veya içecekler, pişirilir ya da isttılır. Isıtma-pişirme elemanı olarak ocak, firın, mikrodalga firın, fritöz, ızgara, tost makinesi, su 1sıtıcısı, çaycı ve kahve makinesi gibi çoğu elektrikli mutfak cihazları kullanılmaktadır. Pişirme ekipmanı, yangından kaynaklı ölümlerin \%14'üne neden olmaktadır. Ocak ve pişirme ekipmanı,mutfak yangınlarının yaklaşık üçte ikisini oluşturmaktadır. Ayrıca pişirme yangınlarının çıkmasında başlıca etken, ocak üstünde ya da fritöz kullanılarak yapılan kızartma işlemidir. Amerika da ev yangınlarının \%15'i, İngiltere de gerçekleşen ev yangınların ise \%52'si pişirme ekipmanlarıkaynaklıdır. Bu yangınlarda yüzlerce kişi ölmüş, binlerce kişi yaralanmış ve büyük maddi zararlar yaşanmıştır (Department for Communities and Local Government, 2015; Chow, 2019; Tüyander, 2020).

Mutfaktaki yangınlar, yangınların genel meydana gelme sebeplerinde olduğu gibi başlica korunma önlemlerinin alınmaması, bilgisizlik, ihmal, kaza ve sıçrama gibi genel sebeplerle çıkmaktadır. Ocak üstünde unutulan yemekler veya içecekler ihmal sebepli yangınlardır. Ocaktan alev ya da sıcak yağ sıçraması, yiyecek ya da içeceğin taşması veya dökülmesi e-ISSN: 2148-2683 ile meydana gelen yangınlar sıçrama kaynaklı yangınlardır. Pişen gıdanın veya pişirme aletinin gereğinden fazla 1sınması, mikrodalga firına metal konması, davlumbaz yangınları ve yağ yangınları bilgisizlikten dolayı çıkan yangınlardır.

Yemek pişirme işlemi, yangının meydana gelmesi için gereken tutuşma noktasına yetecek 1S1 kaynağını sağlayan olaydır. Isı kaynağı olarak elektrik ya da gaz yakıt kullanan birçok mutfak ekipmanıkullanılmaktadır.Yemekler, ızgara haricinde ya su ya da yağ gibi isıyı taşıyan bir ortamda pişirilir. Mutfaklarda kaynar su ve kızgın yağın taşması, dökülmesi ve sıçraması dolayısıyla yangınriski vardır. Özellikle yağın tutuşma sıcaklığının yüksek olması ve bu sıcaklıkta mutfaktaki birçok malzemenin tutuşma sicaklığına yetecek kadar bir 1 sıl ortam oluşması en önemli yangın sebebidir. Yağın kızgın buharı, önlemler alınmazsa yağ yangınlarına sebep olabilir.Mutfaklarda yemek pişirmek ve kızartmak için isıtılan bitkisel sıvı yağların tutuşma sıcaklı̆̆ına kadar ısınması yağ yangına yol açar. Fritözler gibi yüksek sıcaklıklarda çalışan cihazlarda daha fazla yağ buharı oluşur.

Mikrodalga firın kaynaklı yangınlar pişirme ekipmanı kaynaklı yangınların \%5'ini oluşturmaktadır. Mikrodalga firınlarda mikrodalgaya uygun olmayan metal gibi ışını yansıtan maddeler konulduğunda yangın çıkabilmektedir (Hall, 2008).

Davlumbaz, yemek buharları ve kokularının mutfaktan baca ile dışarı atılmasını sağlayarak mutfağın ve konutun yemek kokusunun atılmasını sağlar. Davlumbaz ve hava kanallarına yemek buharı ve 1sı taşınır. Özellikle yemek yağı buharı havadan ağır olduğu için bacaya, filtrelere veya kanallarda yoğuşarak birikebilir. Bu yapışkan vaksı tabakanın tutuşma sıcaklığı, yağın tutuşma sıcaklığından daha düşük olsa da yağ buharının taşıdığı 1S1, konveksiyonla davlumbaza ve kanallardaki yağ tabakasına taşınır ve yangına yol açabilir. Pişirme ünitelerinden sıçrayan kıvılcım ve sıcak kurumlar, biriken yağ tabakalarını tutuşturabilir. Davlumbaz altında kızartma veya pişirme yaparken parlayan alev yangınlara neden olabilir. Pişirme sonucu oluşan yağ buharı, aşırı 1sıya maruz kalması veya doğrudan aleve temas etmesi ile parlar. Yükselen alevler davlumbaz ve yağ filtrelerine ulaştığında davlumbaz ve kanallardaki biriken yağ tabakasını kolaylıkla tutuşturabilir. Yangın bacaya kadar ilerleyebilir, eğer otomatik söndürme sistemi yoksa ya da çalışmazsa yangın fana ulaşabilir. Davlumbazdaki metal aksamda 1s1 kondüksiyonla hızlıca iletilir,ortamda tutuşabilecek malzemeleri yakarak yangının tüm binaya yayılmasına sebep olabilir (Chow, 2019).

Mutfakta davlumbaz, ocak ya da barbekü gibi cihazların yemek buharlarının atıldığı baca sistemleri bulunmaktadır. Baca içindeki yağ tabakasınasıcak duman ya da buharla 1sı taşındığı için bu yağtabakası tutuşabilir. Bu nedenle baca temiz tutulmalı ve periyodik bakımları yapılmalıdır (Chow, 2019).Mutfak aspiratörü ve bacalardaki is,kurum veya yağ tabakası gibi birikintiler tutuşabilir ve yangına neden olabilir.Gerekli önlemler alınmazsa baca yangınları, çatı yangınına ve bina yangınına sebep olabilir.

Izgara, mangal ve barbekü gibi pişirme cihazları da mutfak yangınlarına neden olmaktadır. $\mathrm{Bu}$ pişirme cihazlarında yanma sonucu ortaya çıkan kül ve kurum düzgün temizlenmediğinde zamanla kanallarda birikir. Kanallardaki bu birikinti, buhar ile temas ettiğinde kuru ve yapışkan bir tabaka oluşturur. Yanmamış ancak yanıcı bu tabakada oksijen yetersizliğinden dolayı eksik yanma ya da cihazın teknik özelliklerinden dolayı kısmi eksik 
yanma meydana getirir. Bu tabaka yanıcı özellikte olduğundan 1sı altında yanar ve yangına yol açabilir.

Yemek pişirirken ocaktaki alevle elbise, gömlek veya bluzun geniş uzunkolu temas etmesi sonucu da yangınlar çıkabilmektedir. Mutfak yangınları kış aylarında genelde daha fazla meydana gelmekte olup, uzun kollu giysiler havanın soğuk olduğu kış mevsiminde giyilmektedir. Havanın sıcak olduğu yaz aylarında giysinin uzun kolundan meydana gelebilecek bir yangın riski yoktur denilebilir. $\mathrm{Bu}$ şekilde meydana gelen yangınların pişirme ekipmanı kaynaklı yangınların içindeki oranı $\% 1$ dir (Hall, 2008).

Yakılıp söndürülmemiş kibrit ya da bir maddenin çöpe atılması çöp içinde bulunan tutuşma noktası düşükkâğıt parçaları gibi yanıcı maddelerin tutuşarak yanmasına ve yangına sebebiyet verebilir.

\subsection{Mutfak Yangınları Önlemleri}

Türkiye deki yangınların ikinci çıkış sebebi elektriktir. Mutfaklarda,firın, mikrodalga firını, elektrikli ocak, davlumbaz, mutfak robotu, tost makinesi, elektrikli 1zgara, çay/kahve makinesi, fritöz, ekmek yapma makinesi ve su 1sıtıcısıgibi küçük mutfak ev aletleri ile birlikte buzdolabı ve bulaşı makinesi gibibeyaz eşyalara kadar çok fazla elektrikli alet yer almaktadır. Gerek işyeri mutfakların gerek konut mutfaklarında küçük bir alanda çok sayıda elektrikli cihaz bulunduğundan elektrik yükü ileberaber elektrik yangın riski artmaktadır. $\mathrm{Bu}$ sebeple, mutfaklardaki elektrik tesisatının uzman bir elektrikçi tarafından yapılması, eskiyen tesisat yenilenmesi, kapasite üzerinde mutfak ekipmanı kullanılmaması, aynı prizden çok sayıda elektrikli cihaz beslenmemesi, elektrik prizlerinin topraklı olması ve kullanılmayan ekipmanlar fişten çekilmesi gerekmektedir.Ayrıca mutfaktaki elektrikli küçük ev aletleri sudan uzakta konumlandırılmalıdır.

Mutfakta yangın riski taşıyan elektrik dişındabirçok etmen vardır.Bunlar, ısıtma-pişirme cihazları, ocak, elektrikli cihazlar, tüp, davlumbaz, baca ve çöp kutusu gibi ortamlardır. Isıtmapişirme cihazları, ocak ve elektrikli cihazlar 1sı kaynağı, baca, tüp, çöp ve davlumbazda ise daha çok yanıcı madde kaynaklı yangınlardır. Öncelikle yangın çıkmaması için gerekli önlemler alınmalı ve mutfak, yangın risklerine göre tasarlanmalıdır. Mutfakların yangın güvenlik önlemlerine göre tasarımı, binaların yangından koruma yönetmeliğinin pasif yangın güvenlik önlemlerine göre yapılmalıdır.Pasif yangın güvenlik önlemleri, binaların inşaası aşamasında alınan önlemlerdir ve inşaattan sonra ilave edilmez. Özellikle iş yeri mutfakları, bir yapının genellikle alt katına, üst katına veya binanın dışına gerekli tesisat donatılarak inşaa edilir. Mutfaklarda tesisatta çıkabilecek arızalara zamanında müdahale etmek için uygun konumda inşaa edilemelidir (Ayyıldız, 2019). Kaçış yolları, yangın merdivenleri, yangın kapıları, yangın duvarları ve duman tahliye bacaları gibi pasif yangın güvenlik önlemleri de bina inşaasında tasarlanmalıdır.Aktif yangın güvenlik önlemleri ise binanın inşaatından sonra yangın gerçekleştiğinde kullanılan ilave önlemlerdir. Aktif yangın güvenlik önlemleri, yangını başlangıç anında algılayan ve yangının yayılmaması için gerekli olan yangın güvenlik sistemleridir. Özellikle iş yeri, hazır yemek sektörü ve lokantaların mutfaklarının yangından korunması için öncelikle alınması gerekli önlemlerdir. Aktif yangın algılama ve söndürme sistemlerinin eksikliği nedeniyle yangınlardaönemli kayıplar yaşanmaktadır. Alev-duman algılama sistemleri, köpüklü-gazlı söndürme sistemleri, yangın kontrol paneli, alarmlar, sabit boru tesisatı, yangın dolapları veyangın söndürme tüpübaşlıca aktif yangın güvenlik önlemlerindendir (Çelik, 2019; Y1ld1z ve Köse, 2020).

Ocak üstünde unutulan yemekler veya içecekler, taşma, dökülme, sıçrama, pişen gıdanın veya pişirme aletinin yanması ile yangın meydana gelebilir. Bu sebeple yemek pişine kadar ocağın yanından ayrılmamalı ya da ayrılma durumunda ocak kapatılmalıdır. Yatmadan önce ocakta bir şeyler bırakılmamalıdır. Mutfaktan ayrılma durumunda pişirme aletinin 1sısı düşürülmeli ya da kapatılmalıdır.Ocakta taşma ve dökülme durumunda alevin sönmesi yanmayan gaz olası ufak bir kıvılcım ile patlayabilir. Alevsiz elektrik indiksiyonlu ocaklarda yangın riski olmadığından ocak seçiminde öncelikle tercih edilebilir ya da daha az maliyetli gaz sızıntısını algılayıp, kapanan ocakları kullanmak ya da satın almak tercih edilmelidir (Chow ve $\mathrm{N}_{1}$, 2014). Taşması muhtemel yemekler pişirilirken daima kısık ateşte ve derin bir kapta veya kabı tamamen doldurulmadan kullanılmalıdır. Mümkünse, zamanlayıcı özelliğini olan pişirme cihazları tercih edilmelidir. Mikrodalga firın zamanlama özelliğ olduğundan 1sıtma işlemlerinde tercih edilebilir ancak metal kap kullanılmamalıdır.

Yemek pişirirken ocaktaki alevle temas edip yanabilecek salaş, bol ve dökümlü uzunkollu giysiler giyildiğinde dikkat edilmelidir. Mutfakta pişirme-ısıtma işi yapıldığında giysinin kolu siyrilmalidır.

Evcil hayvanlar ve çocuklar ocak ile firından uzak tutulmalı, her zaman denetlenmelidir. Çocukların çaydanlık, tava ve tencere kulplarına ulaşmaları engellenmeli veya tehlike oluşturmayacak şekilde konumlandırılmalıdır.Tencere ya da tavanın kulpu,devrilmeyi önlemek için ocağın üzerine sapları içeri doğru olmalıdır. Tencere veya tava kulpları sıcaksa bir tutacakla tutulmalı veya kulpu isıl yalıtkan olan kapların kullanımı tercih edilmelidir. Tava veya tencerelerde küçük bir parlama olduğunda, kimyasal tozlu yangın söndürücülerinde içeriğinde bulunan aynı zamanda hamur işlerinde çokça kullanılancep sodası (bikarbonat) ile yangın söndürülebilir. Bu yüzden, ocağın yanında, görülebilecek veya ulaşılabilecek konumda cep sodası bulundurulabilir.

Firınlar termostatlı olup, 1S1 ve zaman kontrolü yapılabilen bir mutfak cihazıdır. Ancak olası yangına karşı firın etrafında yanmaz, 1sıl yalıtkan koruyucu bir panel olursa yangın riski ortadan kaldırılabilir. Lavabo, bankonun üstü ve mutfak dolapları yanmaz bir kaplama ile kaplanabilir. Mutfak dolapları genellikle ahşap mobilya olup, yangın çıkması durumunda tahtanın tutuşma noktasının düşük olmasından dolayı kolaylıkla tutuşabilir ve yangının büyümesine neden olabilir. Bu sebeple mutfak dolapları A1 veya A2 sınıfi yanmaz bir kaplama ile kaplanabilir ya da yanabilirliği düşük bir malzemeden yapılan mutfak dolapları tercih edilebilir. Ocak ya da firından olası alev ya da kıvılcım sıçramalarına karşın ocağa veya firına yakın kurutma bezleri, mutfak havlusu, peçete, kağıt havlu, firın eldivenleri, örtü ve diğer yanıcı herhangi bir madde bulunmamalı veya en az 1 m uzakta olmalıdır (İnan ve ark., 2007). Ayrıca ocak yakındabulunan perde ve güneşlikler, rüzgâr ile ocağın açık alevine yaklaşması nedeniyle tutuşabilir. Bu sebeple rüzgarda hareket etmeyecek stor perde ya da yanmaz kumaştan perde tercih edilebilir. Ayrıca ateş kaynağı olabilecek ocak, firın veya ızgara perdeye uzak bir konuma yerleştirilebilir.

Su kaynatırken kullanılan kapları tamamen doldurmayarak taşma önlenebilir. Ayrıca kaynar suyu başka bir kaba aktarmak için 1S1 iletmeyen kaplar kullanmalıdır. Sıvı yağ kapta yavaş 
yavaş kızdırmalı, uygun büyüklükte tencere kullanılmalı, kabın en fazla üçte biri yağ ile doldurulmalı ve ocak yağın sıçramasını önleyecek şekilde 1sitılmalıdır. Mümkünse otomatik sıcaklık ve zaman kontrollerine sahip elektronik derin bir fritöz kullanılmalıdır. Sıvı yağ yangınlarını söndürmek için kesinlikle su kullanılmamalıdır. Yağ buharının sıcaklığı suyu buharlaştırarak genleşmesine,yangının büyümesine ve yayılmasına neden olur. Kızartma esnasında yağ buharının parlaması veya alev almasını engellemek için öncelikle 1S1 kaynağını ortadan kaldırmak için ocak kapatılmalı daha sonra hava ile teması kesmek,boğmak için kapak üzerine kapatılmalı, kap hareket ettirilmemeli ve soğuduğundan emin olmadıkça kapak açılmamalıdır (Mamacıoğlu ve ark., 2017; Razon ve Ahmad, 2017; Ling Hsu ve ark., 2019).

Kızgın yağ, kaynama noktasının yüksek olması nedeniyle tehlikelidir. Mutfakta pişirme ve kızartma için zeytinyağı, ayçiçek yağı, kanola, fındık yağı ve mısır yağı gibi bitkisel sıvı yağlar kullanılmaktadır.Bu yağlar arasından daha ucuz olduğu için ayçiçek ve mısır yağı daha çok kullanılmaktadır. Ayçiçek yağının dumanlanma noktası $209-213^{\circ} \mathrm{C}$ arasındadır. Dumanlanma noktası, yağların 1sıtma sırasında sürekli duman oluşturduğu sıcaklıktır. Duman yanmamış partiküllerin havada asıltı halinde taşındığı bir aerosoldur. Kızartma sırasındaki yağların dumanlama noktası değeri için bir limit belirlenmiştir, örneğin ayçiçek yağı için bu yasal limit $170{ }^{\circ} \mathrm{C}$ dir (Yaşdağ ve Tekin, 2017). Yağı fazla ısıtmamak sağlık ve güvenlik açısından önemlidir. Yağın alev aldığı zamanki sıcaklığı $675^{\circ} \mathrm{C}$ ye kadar çıkabilmektedir (Chow, 2019). Sıcak yağ döküldüğünde veya deriye sıçradığında çok ciddi yanıklara neden olur. Kaynar su ve kızgın yağ nedeniyle oluşan yanıklar, çoğunlukla 2. veya 3. derece yanıktır. 2. derece yanıkta deri su toplayarak kabarcıklanır ve acı verir. 3. derece yanık, derinin kömürleşecek derecede kavrulması şeklinde gerçekleşen yanıktır. Cildin tüm katları, cilt altı yağ ve kas, tendon gibi derin yapılarda kömürleşmiş görünüm vardır (Shrader, 2012).

Kızgın yağda pişirilecek ya da kızartılacak gıda kuru olmalı, suyu süzülmeli veya donmuş gidalar tamamen çözündürüldükten kullanılmalıdır. Aksi taktirde kızgın yağa giren su, hızlıca buharlaşıp yağın sıçramasına neden olur. Kaynar su ve kızgın yağ ile çalışırken, içinde bulundukları kabın devrilmesi ciddi bir tehlike oluşturur. Bunun için kaynatma veya kızartma kısa saplı tava veya kaplarda ocağın uzak köşesinde yapılmalıdır.

Davlumbaz yangınlarının önüne geçmek için davlumbaz temizliğine dikkat edilmeli, filtreler ve hava kanalı düzenli temizlenerek yağ tabakasının oluşması engellenebilir. Ayrıca gerektiğinde filtreler değiştirilmelidir. Davlumbaz bacalarından çıkan hava kanalının mutfaktan çıktığı kısma yağ toplama çekmecesi yerleştirilebilir. Binaların yangından korunması yönetmeliğine göre konut dışındaki alışveriş merkezleri ile yüksek binalarda bulunan mutfaklar ve yemek fabrikaları ile bir anda 100'den fazla kişiye hizmet veren mutfakların davlumbazları için otomatik söndürme sistemi zorunludur. Ancak konutlarda kullanılan davlumbazlar için de yetkili bir firmaya otomatik söndürme sistemi yaptırılabilir (BYKHY, 2015)

Baca yangınları, yangınların başlıca nedenidir. Ülkemizdeki yangınların \%8 i bacadan kaynaklanmaktadır. Dolayısıyla bacaların temizliği ve yalıtımı çok önemlidir. Doğalgaz bacaları yılda bir, normal bacalar yilda iki, lokanta ve yemekhane bacaları ise 15 günde bir defa yetkili firmalara temizlettirilmelidir. Çatlak bacalar tamir ettirilmeli, tıkalı bacalar ise mutlaka açtırılmalıdır. Biriken kurumlar, baca yangını şeklinde ortaya çıkmasa dahi, baca çekişini engelleyerek, yanma verimini düşürmekte, tütme ve dumanın geri tepmesi ile karbon monoksit zehirlenmeleri nedeniyle ölüm getirmektedir.

Mutfaklarda, balkonlarda ya da bahçelerde 1zgara için kullanılan mangal ve barbekülerde yangın tehlikesi barındırmaktadır. Barbekü düz bir zemin üzerine yerleştirilmeli ve etrafında yanıcı bir madde bulunmamalıdır. Barbeküyü canlandırmak için benzin, kolonya ve parafin gibi tutuşma noktası düşükmaddeler kullanılmamalıdır. Özellikle katı yakıt kullanılan 1zgaralarda pişirilen balık ve et fazla yă̆ buharı oluşturduğundan pişirme işleminden sonra 1zgara ve kanallar tortu kalmayacak şekilde çok iyi temizlenmelidir.

Mutfaklarda enerji kaynağı olarak çoğunlukla LPG veya doğalgaz gibi gaz yakıtlar kullanılır. Gaz kullanılan mutfaklarda havalandırma sistemi veya havalandırma boşluğuolmalıdır. Böylece gaz kaçağı durumunda, gaz bu havalandırma sayesinde ortam dişına atılacaktır. Doğalgaz kullanılan alanlarda doğal gazın havadan hafif olması ve olası sızıntıda tavanda birikmesi nedeniyle havalandırma tavana yakın olmalıdır. LPG kullanılan alanlarda ise LPG nin havadan ağır olması ve olası sızıntıda yerde birikmesi nedeniyle havalandırma yere yakın olmalıdır. İyi bir havalandırma için mekanın boyutuna göre gerekli saatteki hava akımı yani havanın hacimsel debisi bilinmelidir. İngiliz standartlarına göre antre için $1 \mathrm{~m}^{3} / \mathrm{h}$, banyo ile tuvalet için 2 $\mathrm{m}^{3} / \mathrm{h}$, oturma odası ve yatak odas 1 için $12-21 \mathrm{~m}^{3} / \mathrm{h}$, mutfak için $56 \mathrm{~m}^{3} / \mathrm{h}$ olması uygundur. Yap1 bölümünde en fazla hava değişim miktarı mutfakta olması gerektiği bu standartda görülmektedir (Kars, 1999).

Gazlı ocaklarda bağlantı noktaları düzenli olarak kontrol edilmeli ve uygun gaz algılama sistemi kullanılmalıdır. Böylece gaz kaçağı fark edilerek engellenebilir.Binaların yangından korunması yönetmeliğince konut dışındaki alışveriş merkezleri ile yüksek binalardaki mutfaklar ve yemek fabrikaları ile bir anda 100 'den fazla kişiye hizmet veren mutfakların ocaklarında kullanılan gazın özelliklerine göre gaz algılama, gaz kesme ve uyarı tesisat zorunludur (Shrader, 2012). Gaz kaçağı olduğu durumda, ısıya neden olacak bir şey yapılmamalıdır, sigara yakılmamalı, herhangi bir şeyin kapağını açarak statik elektriğe yol açılmamalı ve gaz sızıntısı kesilerek ortam havalandırılmalıdır. LPG tüpleri dik tutulmalı, bağlantı hortumları kontrol edilmeli, eskimiş ise yenilenmeli ve 1.25 m'den uzun bağlantı hortumu kullanılmamalıdır. Arızalı dedantör değiştirilmeli ve her tüp değişiminde contalaryenilenmelidir. Piknik tüpleri üzerine geniş tabanlı tencereler koyulmamalıdır. Kaçak tespiti için sabun ya da deterjan köpüğü kullanılabilir. Parlayan tüpler kesinlikle pencereden veya balkondan dışarı atılmamalı, hareket ettirilmemeli, alevin üzeri varsa yangın battaniyesi ya da islak bir bezle sarılıp vanası kapatılmalı veya yangın söndürücü kullanılarak yangın söndürülmelidir.

Mutfakta kullanılan her türlü alet, cihaz ve malzeme yanmaya karşı dayanıklılık ya da kolay söndürülebilir olma koşulları yerine getirenlerin üretime uygun kabul edilip üretilmesi yangın güvenliği açısından son derece önemlidir. Mutfakta kullanılan her alet, cihaz ve malzeme teknik özelliklere uygun olarak üretildikten sonra Avrupa birliği standartlarındaki performans testleri uygulanmakla beraber yangınla ilgili ek testler yapılmaktadir.

Yangınları önlemek her zaman söndürmekten daha kolaydır.Mutfak yangınları sıklıkla yaşandığı için mutfak 626 
yangınlarının otomatik söndürülmesi yangın güvenliği açısından önemlidir. Özellikle iş yeri mutfakları, lokantalar ve yemek hizmeti veren mutfaklarda söndürme sistemi olmalıdır. Mutfaklarda da otomatik ve manuel söndürme sistemi ve ekipmanları eksiksiz ve her an çalışabilir olmalı, kullanıcı bilgilendirilmeli ve deneme yapmalıdır. Her mutfakta uygun bir yangın söndürücü tüp ile yangın battaniyesi bulunmalı, kolayca ulaşılabilecek ancak yemek pişirme alanından uzağa konumlandırılmalıdır.Bir yangın durumunda ise yangının çıktığı mutfaktan diğer bölümlere yangının yayılmaması için gerekli bölümlemeler olmalı ve yalıtım sağlanmalıdır. Özellikle iş yeri mutfakları, hazır yemek sektörü mutfaklarında binaların yangından korunması yönetmeliğine göreen az 120 dakika yangına dayanıklı olarak bölümlendirilmeli ve duman sızdırmaz kapılar kullanılmalıdır (BYKHY, 2015; İnce, 2016).

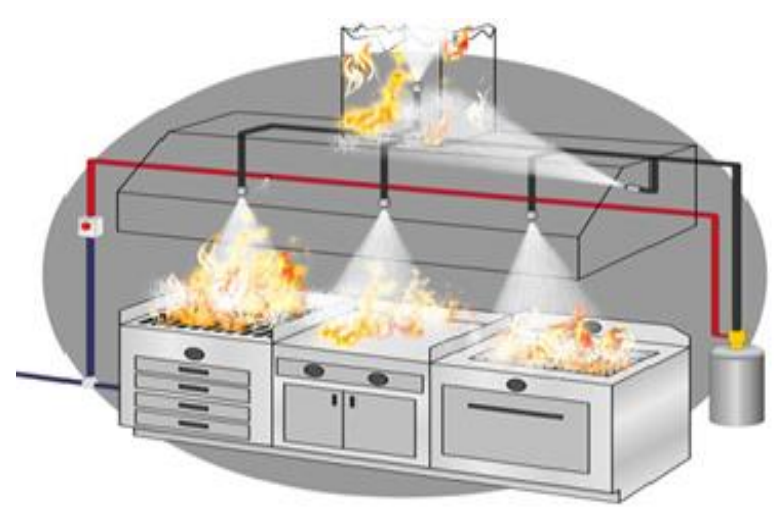

Şekil 4. Mutfak Yangın Söndürme Sistemi

Her yıl restaurantların \%20 sinde mutfak yangın çıkmakta ve önemli ekonomik kayıplar yaşanmaktadır. Mutfak malzeme maliyetinin $\% 5$ 'i kadar düşük bir bütçe ile basit yangın söndürme sistemleri mutfakta kullanılarak yangın önlenebilir ya da en az hasarla atlatılabilir. Ayrıca mutfaklarda yangın riski oluşturabilecek etmenler belirlenip, yangına müdahale konusunda mutfak çalışanlarına eğitim verilerek yapılacak tatbikatlarla yangınlar önlenebilir (Mamacığlu ve ark., 2017; Tüyander 2020).

Yangının çıkmaması, büyümemesi, yayılmaması ve nasıl müdahale edileceği konusunda ev halkı ya da mutfak çalışanları bilgilendirilmelidir. Mutfakta yangın güvenliği için alınacak tedbirler sekiz madde de özetlenebilir (Razon ve Ahmad, 2017):

- Yemek pişirirken daima mutfakta kalınmalı.

- Bulaşık bezleri, kağıt veya plastik poşetler, kaplar ve perdeler gibi alev alabilecek her şeyocak gibi 1sı kaynaklarından en az 1 metre uzakta tutulmalı.

- Gevşek kıyafetler ocağın bekindeki açık aleve temas edebilir ve alev alabilir. Böyle bir durum söz konusu olduğunda dur, yat ve yuvarlan kuralı uygulanmalı.

- Ocak, tost makinesi ve firın gibi 1sıtma-pişirme cihazlarını temiz tutulmalı.

- Her zaman güvenilir bir markanın, test edilmiş ve onaylanmış pişirme ekipmanı kullanılmalı.

- Pişirme bölgesindenbir metrelik "çocuksuz bölge" oluşturarak çocukları ve evcil hayvanları pişirme alanlarından uzak tutulmali.

- Yağı yavaşça 1sıtılmalı, yağın bulunduğu tava veya tencerenin kapağını yanmaz firın eldiveni ile tutulmalı. Sıçrayan yağa karşı korunmalı.
- Alet ve malzemeler devrilmeyecekleri sabit duracak bir yere yerleştirilmeli.

\section{Sonuç}

Konutlarda meydana gelen yangınların yarısı mutfakta gerçekleşmektedir. Mutfakta yangın güvenlik önlemleri alınmadığında ya da yetersiz olduğunda mutfakta başlayacak yangın hızla büyüyüp yapının diğer bölümlerine yayılabilirve hane halkının ölümü ile beraber büyük maddi zararlara sebebiyet verebilir.Avrupa birliği standardında veya ABD'de uygulanması zorunlu olan yangın güvenlik standartlarını belirleyen ve yayınlayan NFPA nın tasarım hesapları, filtre maddeleri ve hava girişleri gibi alanları kapsayan teknik yönergelerden faydalanılarak ülkemizde yangın güvenliği için esasalınan binaların yangından korunması yönetmeliğidüzenlenebilir. Özellikle iş yeri mutfakları, yemek servisi yapan mekanların mutfaklarında, yangın riskleri değerlendirilmeli ve gerekli yangın güvenlik önlemleri alınmalıdır. Ayrıca mutfak çalışanlarına yangın güvenliği hakkındaeğitim verilerek bilgisizlik ve ihmal sebebiyle çıkabilecek yangınların önüne geçilebilir.

\section{Kaynakça}

Ahrens, M.(2007), Home Kitchen Fires Reported to US Fire Departments, Residential Kitchen Fire Suppression Research Needs: Workshop Proceedings

Ayyıldız S., (2019), Turistik Konak İşletmelerinde Mutfağın Fiziksel Koşullarının Önemi: Safranbolu Yöresel Mutfak Mimarisi Üzerine Bir Araştırma, Journal of Humanities and Tourism Research, 9(2), 610-625

Bakırc1, A.E. http://imoistanbul.org/imoarsiv/2015seminernotlari/2015kasim/2016-01-04-erhan-bakirci/seminer-notu.pdf (Erişim Tarihi: 03.05 2020).

Binaların Yangından Korunması Hakkında Yönetmelik, (2015). Binaların Yangından Korunması Hakkında Yönetmelikte Değişiklik Yapılmasına Dair Yönetmelik.

Chow, W.K.(2019), Yüksek Binaların Küçük Konut Birimlerinde Açık Mutfaklara İlişkin Yangın Güvenlik Kaygıları, TÜYAK Yangın Mühendisliği Dergisi, 9:42-46

Chow, W.K.,N1, X.(2014). Experimental Evaluation on Performance of Open Kitchen Fire Suppression Systems, Fire Safety Science-Proceedings of The Eleventh International Symposium, 1298-1311

Çelik, G.(2019),Üniversite Araştırma Hastanelerinde Aktif Yangın Güvenlik Önlemleri, Tarsus Üniversitesi Lisansüstü Eğitim Enstitüsü, Yüksek Lisans Tezi.

Department for Communities and Local Government, 2015. Fire statistics: Great Britain April 2013 to March 2014

Hall, J.R.(2008). Home Fires Involving Cookıng Equipment, Fire Analysis and Research Division National Fire Protection Association 
Hsu, W.L., Jhuang, J.Y., Huang, C. S., Liang, C.K., Shiau, Y.C., (2019), Application of Internet of Things in a Kitchen Fire Prevention System, Appl. Sci., 9, 3520, 1-22

https://tuyander.org.tr/2019/11/07/mutfak-yanginlari/ (Erişim Tarihi: 03.05 2020).

İnan, H.F., Kurt, Z., Kubilay, İ.(2007), Temel İlk Yardım Uygulamaları Eğitimi

İnce, A.(2016), Hastanelerde Yangın Güvenliği ve Tahliye Gerekleri Üzerine Bir İrdeleme. Üsküdar Üniversitesi Sağlık Bilimleri Enstitüsü, Yüksek Lisans Tezi.

İstanbul Büyükşehir Belediyesi İtfaiye Daire Başkanlığı, (2020), Yangınlarına karşı alınması gerekli tedbirler, İstanbul İtfaiyesi, (Erişim Tarihi: 03.05 2020).

Kara, İ.B.(2018),2013-2017 Y1llar1 Arasında Artvin İl Merkezinde Meydana Gelen Bina Yangınlarının İncelenmesi, Doğal Afetler ve Çevre Dergisi, 42: 105-114

Kara, İ.B., Kara C. (2018), Bina Yangınları ve Maddi Zararın İncelenmesi Üzerine Bir Çalışma: Gümüşhane İli Örneği, Mühendislik Ve Mimarlık Çalışmaları

Kars, F.(1999), Yapılarda Yangın Riskini Sınırlamaya Yönelik Önlemler ve Duman Kontrolünün Sağlanması, VI. Ulusal Tesisat Kongre ve Sergisi

Kılıç, A., (2014), Konutlarda Yangın Kaçışları, Yangın ve Güvenlik Dergisi,165, 2-3.
Kılıç, A., (2018), Gelişmiş Ülkelerde ve Türkiye'de Yangın Nedenleri, Yangın ve Güvenlik Dergisi, 200, 8-10.

Mammacioğlu, O., Coşkun, G., Soyhan, H.(2017), Su ile Karışmayan Yağ B, F, K Sınıfı Yangınlarında Yangın Söndürme Cihazlarının Doğru Kullanımı. Uluslararast Yakıtlar Yanma ve Yangın Dergisi, 5:19-23.

Mersin Büyükşehir Belediyesi İtfaiye Daire Başkanlığı, (2020), İstatistikler, Mersin İtfaiyesi.

NFPA, National Fire Protection Association, (Erișim Tarihi: 03.052020 ).

Razon, A.A, Ahmad, I.(2017),A Study on Fire Safetyand Security at Kitchen in Apartment Buildings, International Journal of Latest Engineering and Management Research IJLEMR, 23:62-71

Shrader, K.W. (2012), Strategies for Reducing Residential Cooking Fires

Yaşdağ, T., Tekin, A., (2017),Ayçiçek ve Pirina Yağlarının Kızartma Stabilitelerinin Karşılaştırılması, Gıda, 42(2): 105115

Yıldız, Z., Köse, E., (2020), Motorlu Araç Yangınları Üzerine Bir İnceleme, EJOSAT, 19, 119-126 